\title{
STRATEGIC RISK MEASURES IN ROAD TRAFFIC
}

\section{MIARY RYZYKA STRATEGICZNEGO W RUCHU DROGOWYM}

\author{
Kazimierz Jamroz \\ Department of Highway Engineering, Faculty of Civil Engineering and Environment, \\ Gdansk University of Technology, 11 Narutowicza str, 80-232 Gdansk, Polska \\ Katedra Inżynierii Drogowej, Wydział Inżynierii Lądowej i Środowiska, \\ Politechnika Gdańska, ul. Narutowicza 11, 80-232 Gdańsk, Polska \\ kjamroz@pg.gda.pl
}

\begin{abstract}
Strategic risk is a long-term risk which forms part of long-term decisions taken by organisations which manage road safety in a specific area. The strategic risk on a country's road network is the uncertainty about the strategic goal which is to protect road users from death and injury. When estimating risk in traffic engineering it is important to use the right measures of risk and methods for calculating or forecasting risk. The paper presents an analysis of macro level measures of strategic risk in road traffic.
\end{abstract}

Key words: road traffic, safety, strategic risk, measures of risk.

Streszczenie. Ryzyko strategiczne jest ryzykiem dtugookresowym, zwiazanym z podejmowaniem decyzji dtugofalowych, przez instytucje zarzadzajace bezpieczeństwem ruchu drogowego na analizowanym obszarze. Ryzyko strategiczne na sieci dróg wybranego kraju jest niepewnościa dotyczaca realizacji celu strategicznego, jakim jest ochrona życia $i$ zdrowia uczestników ruchu drogowego. Istotnym problemami $w$ szacowaniu ryzyka $w$ inżynierii ruchu drogowego jest przyjęcie właściwych miar ryzyka oraz metod jego obliczania lub prognozowania. W referacie przedstawione będzie analiza miar ryzyka strategicznego w ruchu drogowym na poziomie makro.

Stowa kluczowe: Ruch drogowy, bezpieczeństwo, ryzyko strategiczne, miary ryzyka. 


\section{Introduction}

A road transport safety system is part of the transport system. It comprises tangible and intangible elements designed to work together in a specific environment and under specific conditions to deliver safety. The basic methods of road safety management are risk management and hazard management.

Risk is a combination of the probability of a hazard becoming released in an undesirable event and the damage resulting from the hazard; it is usually the product of the probability that a hazard will be activated in an undesirable event and the level of the damage caused. Road traffic risk is a measure of the seriousness of a hazard. It is defined as a combination of the probability of a road accident and the level of injury and financial, economic and environmental damage.

A hazard is the source of an undesirable event. If placed in unfavourable conditions a road traffic hazard may cause damage as a result of an accident. In the case of road users, this could be the possibility that a car will skid if the driver goes too fast on a wet surface and hits a tree. In this case the hazard will be that the driver will suffer an injury (in the car accident when the car hits the tree) and the risk is the probability of the consequences (in this case of becoming a fatality).

Because the methodology of risk management in road transport is still in the early stages of development, it does not have uniform standards unlike the chemical or power engineering industry or other types of transport. Despite that there are elements of risk management used as a tool to support decision-making at different levels of management, e.g. in [1], [2], [3]:

- road infrastructure management: planning, design and operation of road tunnels, road infrastructure safety management, road planning, road safety audits;

- road traffic management: road network, automation of traffic management;

- management of passenger and freight road transport: movement of hazardous materials, occupational risk of motor transport companies, risk of mass transport;

- individual road user's process of driving: models of driving, risk calculators, risk maps.

Unlike many fields of technology, road transport still has not developed a single method for risk management. However, work is under way to build the basis of the methodology centred around five standard elements: risk 
analysis, risk evaluation, risk treatment, risk monitoring and risk communications [4].

\section{Strategic risk}

Strategic management is a process in which an organisation sets objectives, defines how the objectives will be accomplished (in a policy) and secures the necessary resources to deliver the policy [5]. The objectives of a country's strategic safety plan may be to:

- protect the public against dangerous people (terrorists),

- protect the public against dangerous goods (industrial accidents, toxic waste),

- protect road users from death and injury,

- protect critical infrastructure (including transport infrastructure),

- strengthen the emergency system (including road rescue).

There is a degree of uncertainty involved in accomplishing the objectives. This is due to the volatility of the factors affecting the accomplishment of goals, the complexity of the problem, ignorance of safety managers, lack of precise methods for risk estimation and assessment and lack of information on the part of the partners (local governments, organisations dealing with safety, the public).

Strategic management can use risk management as one of its tools which in this case is strategic risk management. This risk includes the risk to reputation, environment, safety, projects, programmes, etc.

For the purposes of this paper it is important to introduce a division into risk management levels, types of risk and types of damage.

The level of risk management is associated with the position of a risk management organisation in the hierarchy and with the time horizon. Risk may be strategic, tactical and operational.

Strategic risk is a long-term risk and forms part of long-term decisions taken by organisations which manage road safety in a specific area of the country. Tactical risk is a medium-term risk and involves risk management by intermediary levels.

Operational risk is a short-term risk and forms part of the day-to-day business of a road authority or a road safety organisation.

Strategic risk in the road transport system of a selected country is the uncertainty of whether the strategic goal of protecting transport users from death and injury can be accomplished. Generally, when thinking about risk 
we must think in terms of the uncertainty of the consequences. Risk is seen as the uncertainty of:

- total cost (social, economic) incurred in road traffic on a country's transport network, here referred to as societal risk,

- the amount of cost including that of a transport disaster, here referred to as collective risk,

- average cost per inhabitant or road traffic user, here referred to as individual risk.

Strategic risk includes the following types of risk:

- societal risk:

- overall,

- normalised,

- collective risk,

- individual risk.

Societal risk refers to the behaviour of entire social groups in a given area. It is a consequence (number of victims and the costs of accidents) over a specific period (usually per year) in a specific area (continent, country, region, county, city) which is likely to happen as a result of hazardous events released by the operation of the road transport system. This risk applies to everyone living in the area in question. The risk changes slowly over time and is affected by the country's economic development, social change, better education, etc. Depending on the measure representing a given area, we can distinguish:

- overall (absolute) risk calculated as the total consequence of accidents (number of victims, costs),

- normalised (relative) risk calculated as the total consequence per:

- the population in a given area,

- number of vehicles registered in a given area,

- length of the road network.

Societal risk gives international organisations, governments, local governments and other organisations responsible for safety management (police, emergency services, health care) from a given area the basis for making decisions to improve those elements of the road safety system that cause the highest risks and ensure that money is spent effectively.

Collective risk refers to a group of people who are at or near the risk site. Collective risk is defined as the probability of consequences that will affect a whole group as a result of a specific scenario of an emergency. Collective risk shows how susceptible the road transport system is to accidents with multiple fatalities and is a measure of lack of public acceptance for those 
types of accidents or a measure of general aversion to accidents involving many fatalities. Consequently, it is the probability of damage (number of victims among drivers, passengers and other people and the financial or economic damage) suffered in:

1) a single hazardous event, i.e. determining the severity of a single accident,

2) many hazardous events over a fixed period (usually a year) at a specific site (section between interchanges, junction, tunnel) which is likely to happen as a result of a hazardous event or a group of hazardous events released by the operation of the road transport system (i.e. when a road user is exposed to the hazards caused by road infrastructure and vehicles).

Collective risk informs the decisions of road authorities and helps them treat high risk elements of the road network ensuring that money is spent effectively.

Individual risk refers to the behaviour of individual road users at a site (junction, section between interchanges). It identifies the probability of damage and its severity in a single trip or over a fixed period of time when the road user is exposed to the hazards caused by road infrastructure and other road users. The individual risk of an individual road user is key to understanding the role of road infrastructure and the behaviour of road users which affects how road hazards are created [6]. Individual risk in the strategic sense refers to the average behaviour of the people in a specific country and defines the average probability of damage suffered by one member of the community (per unit of kilometres travelled) in a specific area within a fixed period of time. Based on this risk road authorities manage different levels of risk depending on the type of road and traffic volumes. Individual risk can be controlled and reduced effectively [7], [8].

\section{Models and measures of strategic risk}

One of the purposes of road transport safety research is to quantify the phenomena occurring within the system. It is important to understand the relationships between the objects. For that we need the right quantitative measures about the transport system and how it operates. That way public authorities can take up effective action for the benefit of society as a whole. In order to select the right road safety objectives, we need the underlying information about the objective. If the objective of a national road safety programme is to reduce the concentration of fatalities, it is going to need 
fast and accurate information about the number of fatalities and vehicle kilometres travelled. If collecting the data takes a long time or if the data do not offer the right quality (uncertainty about the estimation of results), the information is useless and pointless.

There is a wide range of safety indicators which help select the right and useful risk models. The indicators support the assessment of different aspects of safety and help with the selection of those measures that can draw on available and reliable data. Considering the above, the following are the selected strategic risk models in road traffic:

- societal risk, overall (absolute):

$$
R S_{O}^{(s)}=E \cdot P \cdot K
$$

- societal risk, normalised (relative):

$$
R S_{N}^{(s)}=\frac{R S_{O}^{(s)}}{E}
$$

- collective risk:

$$
R C^{(S)}=\frac{R S_{O}^{(S)}}{N U E}
$$

- individual risk :

$$
R I^{(S)}=\frac{R S_{0}^{(S)}}{V T K}
$$

Where:

$\mathrm{RS}_{\mathrm{O}}{ }^{(\mathrm{S})}$ - strategic, overall societal risk,

$\mathrm{RS}_{\mathrm{N}}{ }^{(\mathrm{S})}$ - strategic, normalised societal risk,

$\mathrm{RC}^{(\mathrm{S})}-$ strategic collective risk,

$\mathrm{RI}^{(\mathrm{S})}$ - strategic individual risk,

E - risk exposure,

$\mathrm{P}$ - probability of hazardous events,

$\mathrm{K}$ - conseguences in a hazardous event,

NUE - number of hazardous events [thousands of accidents per year]

VTK - vehicle kilometres travelled [billions of vehicle kilometres per year],

When estimating risk and assessing its impacts on road traffic, it is important to adopt the right risk measures and methods for calculating or forecasting the measures. Risk measures can appear in a number of categories of damage. The practice so far has been to adopt many road 
traffic risk measures referred to as road safety indicators. A road safety indicator is an observable and measurable feature of the road transport system which, if present, identifies (with greater or lower probability) the level of road traffic risks. We use them when a specific safety aspect cannot be easily observed, measured or modelled. The previous approach to road safety was based on a number of safety measures. There is no universal risk measure in road traffic.

Today's road safety measures can be divided into absolute and relative measures. Absolute measures are the number of accidents and number of injuries and fatalities. Relative measures are the number of accidents and casualties per the number of population, number of vehicles, kilometres travelled, etc. These measures can be adopted as measures of strategic risk which leads us to the distinction between overall measures (absolute) and normalised (relative) measures. Table 1 shows an overview of selected measures of strategic risk used in road traffic.

Table 1. Selected measures of strategic risk in road traffic

\begin{tabular}{|c|c|c|}
\hline Measure & $\begin{array}{l}\text { Used as a measure } \\
\text { of }\end{array}$ & $\begin{array}{l}\text { Examples of } \\
\text { applications }\end{array}$ \\
\hline Number of fatalities & $\begin{array}{l}\text { Societal risk, } \\
\text { overall }\end{array}$ & $\begin{array}{c}\text { Road safety assessment } \\
\text { in many countries and } \\
\text { regions [1] }\end{array}$ \\
\hline $\begin{array}{l}\text { Density of accidents with } \\
\text { fatalities and severe } \\
\text { injuries }\end{array}$ & \multirow[t]{2}{*}{$\begin{array}{l}\text { Societal risk, } \\
\text { normalised }\end{array}$} & \multirow{3}{*}{$\begin{array}{l}\text { Risk assessment on } \\
\text { road networks } \\
\text { (EuroRAP, AusRAP, } \\
\text { iRAP) [6] }\end{array}$} \\
\hline $\begin{array}{l}\text { Potential to reduce fatality } \\
\text { and severe injury accidents }\end{array}$ & & \\
\hline $\begin{array}{l}\text { Relative rate of fatality and } \\
\text { severe injury accidents }\end{array}$ & Individual risk & \\
\hline Total risk & Collective risk & $\begin{array}{l}\text { Tunnel risk assessment } \\
\text { [7] }\end{array}$ \\
\hline Density of fatalities & \multirow{2}{*}{$\begin{array}{ll}\text { Societal risk, } \\
\text { normalised }\end{array}$} & \multirow{4}{*}{$\begin{array}{l}\text { Risk assessment } \text { on } \\
\text { Poland's roads [1] }\end{array}$} \\
\hline Density of accident costs & & \\
\hline Concentration of fatalities & \multirow[t]{2}{*}{ Individual risk } & \\
\hline $\begin{array}{l}\text { Concentration of accident } \\
\text { cost }\end{array}$ & & \\
\hline
\end{tabular}

To become universal, road safety indicators should meet some general requirements [9], and be: 
- solid, i.e. based on reliable sources of data (with little risk of over or underestimation of the phenomenon, there must be national data sources);

- relevant, i.e. easy to read and understand; this indicator should represent the core of the problem and be clearly and commonly understood as a standard (it should be clear how to understand rising or declining values);

- politically significant (attracting the interest of politicians and the news media); this indicator should respond to technical and organisational measures and political interventions, but should not be easily manipulated;

- representative of different dimensions of safety ensuring consistency between the measures;

- up-to-date and easy to update;

- comparable between different countries; the indicators should be calculated in the same way in different countries and follow the standards of e.g. the UN and OECD.

Analyses were conducted leading to the formulation of basic measures of strategic risk in road traffic covering three types of risk: societal, collective and individual and two categories of costs: human and economic cost. Table 2 lists the measures. Below is a short characteristics of the measures.

Table 2. Proposed measures of strategic risk in road traffic

\begin{tabular}{|l|l|l|}
\hline \multirow{2}{*}{ Type of risk } & \multicolumn{2}{c|}{ Proposed measures } \\
\cline { 2 - 3 } $\begin{array}{l}\text { Societal risk - overall } \\
\mathrm{RS}_{\mathrm{O}}\end{array}$ & \multicolumn{1}{|c|}{ Human } & \multicolumn{1}{c|}{ Economic } \\
\hline $\begin{array}{l}\text { Societal risk }- \\
\text { normalised } \mathrm{RS}_{\mathrm{N}}\end{array}$ & $\begin{array}{l}\text { Mortality per person } \\
\text { MP }\end{array}$ & $\begin{array}{l}\text { Costs of road accidents } \\
\text { CA }\end{array}$ \\
\cline { 2 - 3 } Costs of accidents CAP \\
\cline { 2 - 3 } & Mortality MV & Severity of costs CAV \\
\cline { 2 - 3 } & $\begin{array}{l}\text { Density of fatalities } \\
\text { DF }\end{array}$ & $\begin{array}{l}\text { Density of costs of } \\
\text { accidents DCA }\end{array}$ \\
\hline Collective risk - RC & $\begin{array}{l}\text { Severity of fatalities } \\
\text { SF }\end{array}$ & $\begin{array}{l}\text { Severity of costs of } \\
\text { accidents SCA }\end{array}$ \\
\hline Individual risk - RI & $\begin{array}{l}\text { Concentration of } \\
\text { fatalities CF }\end{array}$ & $\begin{array}{l}\text { Concentration of costs } \\
\text { of accidents CCA }\end{array}$ \\
\hline
\end{tabular}


Measures of societal risk - overall:

Number of fatalities $F$. It is the sum of road accident fatalities in a given area over a fixed period of time. This measure is designed to assess human loss and is often used as the main safety criterion and the goal of safety programmes.

Costs of road accidents $C A$. It is the sum of all economic and social costs of road accidents in a given area over a fixed period of time. The costs are estimated using this relationship:

$$
C A=A \cdot U P D+I \cdot U I+F \cdot U F
$$

Measures of societal risk - normalised:

Mortality per person MP. It is the basic public health indicator and is used to identify the number of victims in the total population living in a given area. In the field of safety this indicator is known as the demographic indicator. The measures are defined using these relationships:

$$
M P=\frac{F}{P}
$$

Accident cost per person CAP. This measure is used to determine the costs of road accidents in relation to the number of population in a given area over a fixed period of time. This measure is calculated using this relationship:

$$
C A P=\frac{C A}{P}
$$

Mortality per vehicle $M V$. This indicator is used to identify the number of accident victims calculated over the total number of vehicles in a given area. In the field of safety this indicator is known as the motorisation fatality rate. This measure is defined with these relationships:

$$
M V=\frac{F}{V}
$$

Accident cost per vehicle $C A V$. This measure is used to identify the costs of road accidents in relation to the number of vehicles in a given area over a fixed period of time. This measure is calculated from the relationship:

$$
C A V=\frac{C A}{V}
$$


Density of fatalities DF. This measure is used to identify the number of accident victims calculated over the total length of the road network in a given area. This measure is defined using this relationship:

$$
D F=\frac{F}{L R}
$$

Density of costs of accidents DCA. It is used to identify the relative costs of road accidents in relation to the length of the road network in a given area over a fixed period of time. This measure is calculated from this relationship:

$$
D C A=\frac{C A}{L R}
$$

Measures of collective risk:

Severity of accidents $S F$. It is a measure of human loss in road accidents calculated as the relationship between the number of victims (injured or killed) and the number of all accidents in a given area within a fixed period. This indicator is defined with the following relationship:

$$
S F=\frac{F}{A}
$$

Severity of costs of accidents SCA. It is a measure of the economic costs of road accidents and is calculated as the relationship between the costs of accidents and the number of all accidents in a given area within a fixed period. This indicator is defined with the following relationship:

$$
S C A=\frac{C A}{A}
$$

Measures of individual risk:

Concentration of fatalities $C F$. This indicator is used to identify the number of accident casualties per total vehicle kilometres travelled in the area under analysis. In the field of safety it is a very popular indicator called the relative casualty indicator. These measures are defined with this relationship:

$$
C F=\frac{F}{V T K}
$$


Concentration of accident costs CCA. This measure is used to identify the relative costs of road accidents per distance travelled by vehicles in the area under analysis and over a fixed period of time. This measure is calculated from this relationship:

Legend:

$$
C C A=\frac{C A}{V T K}
$$

A - number of road accidents

I - number of road accident injuries

$\mathrm{F}$ - number of road accident fatalities

$\mathrm{CA}$ - costs of accidents

UF - unit cost of fatality including economic and social cost

UI- unit cost of injury including economic and social cost

UPD - unit cost of damage of accidents

MP - mortality per person

MV - mortality per vehicle

DF - density of fatalities

$\mathrm{SF}$ - severity of accidents with fatalities

$\mathrm{CF}$ - concentration of fatalities

CAP - costs of accidents per person

CAV - costs of accidents per vehicle

DCA - density of costs of accidents

SCA - severity of costs of road accidents

CCA - concentration of costs of accidents

\section{Conclusion}

One of the basic objectives of strategic road safety management is to protect the population of a country and those visiting it from death and injury in road traffic. The best management method is strategic risk management because it helps identify the hazards, assess risk, select risk reductions measures and secure the necessary resources. The measures proposed in this paper will help with the effective development of strategic risk management.

\section{References}

[1] Jamroz K.: Highway Engineering Risk Assessment. Archives of Transport, vol. 19, Issue 1-2, Warsaw 2007, pp. $67-74$.

[2] Jamroz K.: Koncepcja metody zarządzania ryzykiem w transporcie drogowym dla potrzeb kształtowania bezpieczeństwie ruchu 
drogowego. Przegląd zastosowań zarządzania ryzykiem w transporcie drogowym. ZEUS Raport G2-TD-2/1-A,Gdańsk 2008. (Praca niepublikowana).

[3] Szymanek A.: Koncepcja metody zarządzania ryzykiem w transporcie drogowym dla potrzeb kształtowania bezpieczeństwie ruchu drogowego. Zarządzanie ryzykiem ze szczególnym uwzględnieniem transportu drogowego. ZEUS Raport G2-TD-2/1-B,Radom 2008. (Praca niepublikowana).

[4] Jamroz K., Szymanek A. i inni: Integracja metod zarządzania ryzykiem w transporcie. Rozdz. $7 \mathrm{w}$ pracy zbiorowej pod red. R. Krystka: Zintegrowany System Bezpieczeństwa Transportu, t.2 Uwarunkowania rozwoju integracji systemów transport. WKt Warszawa 2009.

[5]. Schanzer D.H., Eyerman J.: Strategic Risk Management in Government: A Look at Homeland Security. Managing for Performance and Results Series 2009. IBM Center for The Business of Government

[6]. EuroRAP: Getting Organised to Make Roads Safe - EuroRAP 2nd PanEuropean Progress Report Launched, EuroRAP 2006, www. eurorap.net; www.eurorap.pl

[7]. Jamroz K.: The application of risk analysis in the assessment and management of road safety in road tunnels. Journal of KONBiN, 2008

[8]. Jamroz K., Żukowska i inni: Bezpieczeństwo transportu drogowego. Rozdz. $2 \mathrm{w}$ pracy zbiorowej pod red. R. Krystka pt.: Zintegrowany System Bezpieczeństwa Transportu, tom 1: Diagnoza bezpieczeństwa transportu w Polsce. WKŁ Warszawa 2009

[9]. Atkinson T. Europa socjalna a nauki społeczne. Państwo i Rynek numer $1 / 2005$

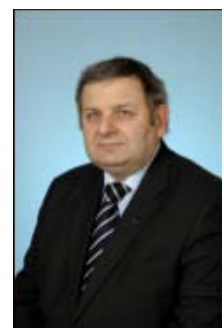

Kazimierz Jamroz Phd Eng., Gdansk University of Technology, Highway Engineering Department, specialization: transportation and traffic engineering, road safety, intelligent transport systems 